\title{
Nestin-positive Stem Cells Participate in Chondrocyte Renewal in Healthy Adult Lung Cartilage
}

\author{
Células Troncales Nestin-positivas Participan en la Renovación de \\ Condrocitos en el Cartílago Pulmonar del Adulto Sano
}

Marta Ortega-Martínez*; Carlos de-la-Garza-González**; Jesús Ancer-Rodríguez* \& Gilberto Jaramillo-Rangel*

ORTEGA-MARTÍNEZ, M.; DE-LA-GARZA-GONZÁLEZ, C.; ANCER-RODRÍGUEZ, J. \& JARAMILLO-RANGEL, G. Nestinpositive Stem cells participate in chondrocyte renewal in healthy adult lung cartilage. Int. J. Morphol., 32(1):151-153, 2014.

SUMMARY: It is considered that healthy adult cartilage has little or no capacity for renewal, and that chondrocytes maintain a stable resting phenotype and resist proliferation and differentiation throughout life. Recently we found that cell turnover in lung cartilage is possible and that nestin-positive cells may have a role in it. In this paper, we report additional findings about chondrocyte renewal in lung cartilage. Lung specimens from CD1 mice at the age of 2, 6, 12, 18 or 24 months were fixed in 10\% neutral-buffered formalin and paraffinembedded. Nestin expression was examined by an immunohistochemical peroxidase-based method. We found nestin-positive cells inside of cartilage islets and cells in division very close from them. Our findings indicate that there exist nestin-positive mesenchymal stem cells in the adult that are able to differentiate into lung chondrocytes, perhaps to maintain homeostasis or repair damaged tissue. These findings may improve our knowledge about the cartilage biology and could provide new cell candidates for cartilage tissue engineering.

KEY WORDS: Cartilage; Chondrocyte renewal; Nestin; Stem cells.

\section{INTRODUCTION}

It is a long held notion that healthy adult cartilage has no, or very little, capacity to renewal and knowledge about how cell division takes place in it is limited (Umlauf et al., 2010). In vivo, chondrocyte turnover has been almost exclusively studied in articular cartilage.

Recently we presented evidence of chondrocyte turnover in lung cartilage. Further, nestin-positive cells were present in connective tissue associated with cartilage, in close proximity of it and in perivascular cells (Ortega-Martínez et al., 2013). Thus, we concluded that cell turnover in lung cartilage is possible and that nestin-positive cells may have a role in it.

Afterwards, we analyzed additional samples to those included in our previous study. Here we report the results.

\section{MATERIAL AND METHOD}

Animals and experimental procedures used were described in a previous paper (Ortega-Martínez et al.).
Briefly, male CD1 mice were examined; three animals were sacrificed at the age of 2, 6, 12, 18 or 24 months. Right lungs were fixed in $10 \%$ neutral-buffered formalin and paraffin-embedded. Serial $5-\mu \mathrm{m}$ sections were cut, deparaffinized in xylene and hydrated in a graded series of alcohol.

The immunohistochemistry for nestin was conducted according to the following protocol: sections were subjected to a heat-induced epitope retrieval step performed by microwave treatment at $89^{\circ} \mathrm{C}$ for $10 \mathrm{~min}$ in $0.01 \mathrm{M}$ citrate buffer ( $\mathrm{pH}$ 6.0). Endogenous peroxidase activity was blocked with $3 \%$ hydrogen peroxide at room temperature for $15 \mathrm{~min}$. The slides were incubated with a monoclonal antibody against nestin (1:100; Millipore, Billerica, MA). Incubations were conducted overnight at room temperature in a humid chamber. Detection was carried out with the Anti-mouse Ig HRP Detection Kit (BD Pharmingen, San Diego, CA) used according to the manufacturer's instructions; diaminobenzidine was applied as chromogen. Slides were counterstained with $0.5 \%$ methyl green. In control experiments, the primary antibody incubation step was omitted.

\footnotetext{
* Department of Pathology, School of Medicine, Autonomous University of Nuevo Leon, Monterrey, Nuevo Leon, Mexico.

** Department of Embryology, School of Medicine, Autonomous University of Nuevo Leon, Monterrey, Nuevo Leon, Mexico.
} 


\section{RESULTS AND DISCUSSION}

Since initially this study was not designed to analyze cartilage, we found it in lung samples from only four mice (4 from a total of 15 mice). We found nestin-positive cells inside of cartilage islets and cells in division very close from them (Fig. 1).

To date, it has been considered that cartilage contains a unique type of cell called chondrocyte. However, the origin of the chondrocyte population and how this population is maintained in the normal tissue in the adult remain unknown (Mathur et al., 2012). In this paper, we present evidence that besides chondrocytes there exist stem cells in lung cartilage. Mesenchymal stem cells (MSCs) are defined as multipotent cells able to differentiate along different pathways including chondrogenic, osteogenic and adipogenic lineages (Keating, 2012). The intermediate filament protein nestin was initially identified as a marker for neural stem cells, but its expression has also been detected in MSCs (Montzka et al., 2009; Sabatini et al., 2005).

Taken together, our findings indicate that there exist MSCs in the adult that are able to differentiate into lung chondrocytes, perhaps to maintain homeostasis or repair damaged tissue. These MSCs might be circulating in the blood stream or remain located in local blood vessels and be able to populate the cartilage (Ortega-Martínez et al.) and/or might reside inside of it (this report).

These findings may improve our knowledge about the cartilage biology and could provide new cell candidates for cartilage tissue engineering. More research is necessary to determine the exact origin of these cells and factors regulating their function.

\section{ORTEGA-MARTÍNEZ, M.; DE-LA-GARZA-GONZÁLEZ,} C.; ANCER-RODRÍGUEZ, J. \& JARAMILLO-RANGEL, G. Células troncales nestin-positivas participan en la renovación de condrocitos en el cartílago pulmonar del adulto sano. Int. J. Morphol., 32(1):151-153, 2014.

RESUMEN: Se considera que el cartílago adulto sano tiene poca o ninguna capacidad para renovarse, y que sus condrocitos permanecen en un estado de reposo estable, careciendo de las propiedades de proliferación y diferenciación. Recientemente encontramos que el recambio celular en el cartílago pulmonar es posible y que células troncales positivas para nestin pudieran tener algún papel en el mismo. En este artículo, reportamos nuevos hallazgos acerca de la renovación de condrocitos en el cartílago pulmonar. Pulmones de ratones CD1 de 2, 6, 12, 18 o 24 meses de edad se fijaron en formalina amortiguada al $10 \%$ y se incluyeron en parafina. Se analizó la expresión de nestin utilizando un método inmunohistoquímico basado en un sistema de detección con peroxidasa. Encontramos células positivas para nestin en el interior de los islotes de cartílago y células en división muy cercanas a ellas. Estos hallazgos indican que existen células madre mesenquimales positivas para nestin en el adulto con capacidad para diferenciarse en condrocitos pulmonares, probablemente para mantener la homeostasis tisular o reparar daños en el tejido. Asimismo, estos hallazgos pueden aumentar nuestra comprensión acerca de las propiedades biológicas del cartílago y podrían proporcionar nuevos candidatos para la ingeniería celular en la terapia regenerativa en enfermedades de las articulaciones.

PALABRAS CLAVE: Cartílago; Renovación de Condrocitos; Nestin; Células Troncales.
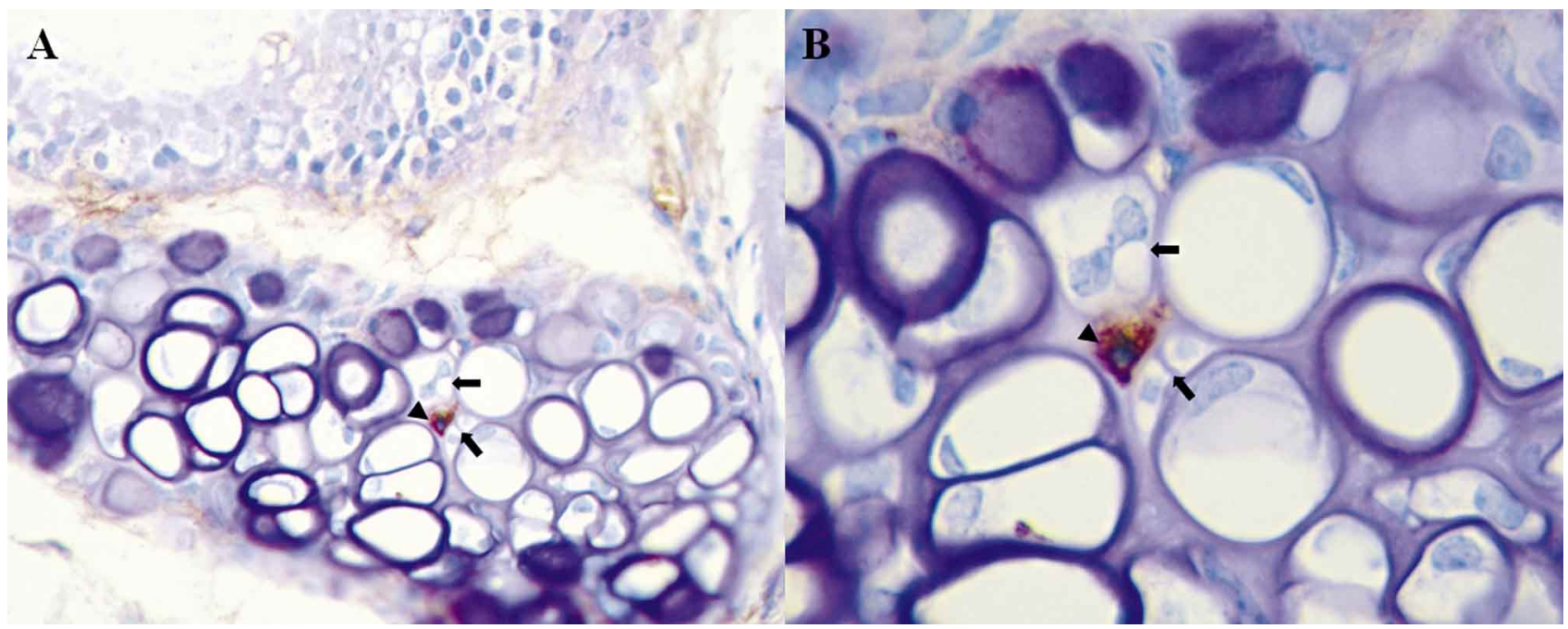

Fig. 1. Detection of nestin-positive stem cells in lung cartilage from a 6-month-old mouse. A. Nestin-positive stem cells were found inside of cartilage islets (arrowhead). Cells in division were observed very close from them (arrows) (X400). B. This is a higher magnification of A (X1000). 
ORTEGA-MARTíNEZ, M.; DE-LA-GARZA-GONZÁLEZ, C.; ANCER-RODRíGUEZ, J. \& JARAMILLO-RANGEL, G. Nestin-positive Stem cells participate in chondrocyte renewal in healthy adult lung cartilage. Int. J. Morphol., 32(1):151-153, 2014.

\section{REFERENCES}

Keating, A. Mesenchymal stromal cells: new directions. Cell Stem Cell, 10(6):709-16, 2012.

Mathur, D; Pereira, W. C. \& Anand, A. Emergence of chondrogenic progenitor stem cells in transplantation biology-prospects and drawbacks. J. Cell. Biochem., 113(2):397-403, 2012.

Montzka, K.; Lassonczyk, N.; Tschöke, B.; Neuss, S.; Führmann, T.; Franzen, R.; Smeets, R.; Brook, G. A. \& Wöltje, M. Neural differentiation potential of human bone marrow-derived mesenchymal stromal cells: misleading marker gene expression. BMC Neurosci., 10:16, 2009.

Ortega-Martínez, M.; Romero-Núñez, E.; Niderhauser-García, A.; de-la-Garza-González, C.; Ancer-Rodríguez, J. \& JaramilloRangel, G. Evidence of chondrocyte turnover in lung cartilage, with the probable participation of nestin-positive cells. Cell Biol. Int., 37(3):239-41, 2013.

Sabatini, F.; Petecchia, L.; Tavian, M.; Jodon de Villeroché, V.; Rossi, G.A. \& Brouty-Boyé, D. Human bronchial fibroblasts exhibit a mesenchymal stem cell phenotype and multilineage differentiating potentialities. Lab. Invest., 85(8):962-71, 2005.

Umlauf, D.; Frank, S.; Pap, T. \& Bertrand, J. Cartilage biology, pathology, and repair. Cell. Mol. Life Sci., 7(24):4197-211, 2010.
Correspondence to:

Gilberto Jaramillo-Rangel

Department of Pathology

School of Medicine

Autonomous University of Nuevo Leon

Avenida Madero y Dr. Eduardo Aguirre P.

Colonia Mitras Centro

Monterrey

Nuevo Leon C.P. 64460

MEXICO

Email: gilberto.jaramillor@uanl.mx

Received: 09-05-2013

Accepted: 19-11-2013 